\title{
The Use of Open Ended versus Closed Ended Questions in Turkish Classrooms
}

\author{
Hamide Çakır ${ }^{1}$, Özge Cengiz ${ }^{2}$ \\ ${ }^{1}$ Department of Foreign Language Education, Niğde University, Niğde, Turkey \\ ${ }^{2}$ Department of Foreign Language Education, İstanbul Medeniyet University, İstanbul, Turkey \\ Email: hamide.cakir@nigde.edu.tr,ozge.cengiz@medeniyet.edu.tr
}

Received 20 February 2016; accepted 19 March 2016; published 22 March 2016

Copyright (C) 2016 by authors and Scientific Research Publishing Inc.

This work is licensed under the Creative Commons Attribution International License (CC BY).

http://creativecommons.org/licenses/by/4.0/

(c) (i) Open Access

\section{Abstract}

Asking students good questions is a critical tool for developing their skills. In particular, open ended questions are believed to be useful for developing students' cognitive skills, as these questions encourage them to express and elaborate upon their thinking, and provide rationales for their thoughts (Lee, Kinzie, \& Whittaker, 2012). Open ended questions are likely to engage children in higher-order thinking (Roth, 1996) and usually involve reasoning and judgment (Hargreaves, 1984). Within this context, this study is an attempt to explore how a training program on open ended questions encourages teachers to improve their classroom practices. In particular, this cross-sectional study focuses on Turkish teachers' questioning strategies, and aims to explore how Turkish teachers benefit from open ended questions in their classes, depending on their experience, gender and the grade of their classes, and to what extent their use of open ended questions differentiate after a training program. At the start of the study, teachers who were teaching Turkish to different grades at different schools were video-recorded in their classes with their students. After the recordings, a teacher training program on the roles and types of question was given to teachers in order to develop their awareness about open ended questions that they use in their classrooms. Following the training, teachers were recorded in their classes in the same way again. Finally, after the discourse transcription, the teachers' questions were classified as open or closed ended, and a comparison of the data recorded before and after the training was designed to determine whether the training course had positive effects on teachers' use of open ended questions. The results of this study indicate that the training encouraged teachers to adopt a more systematic and reflective pedagogical practice. After training, the teachers asked more open ended questions which resulted in more student participation, thus there was more dialogue in the classrooms.

\section{Keywords}

Classroom Discourse, Teachers' Questioning, Open Ended Questions, High-Order Thinking 


\section{Introduction}

Education is fundamentally a process of human interaction, and classroom discourse constitutes the mechanism through which interaction takes place (Nystrand, Gamoran, \& Carbonaro, 2001). The investigation on classroom discourse is of great importance since it mediates pedagogical decision-making and the outcomes of language instruction (Maftoon \& Rezaie, 2013: p. 108). Studies of classroom discourse recognize that the question of how much teachers talk is important, but what is equally important is how effective teachers are in facilitating learning and promoting interaction in their classroom through the type of questions they ask (see Nunan, 1989).

\subsection{Classroom Discourse}

Discourse is the organization of language beyond the level of sentence and the individual speaking turn, whereby meaning is negotiated through interaction (Carter \& Nunan, 2001: p. 221). Nunan (1993) viewed classroom discourse as the distinctive type of discourse that occurres in classrooms. Many researchers have categorized the features of classroom discourse (Chaudron, 1988; Ellis, 1994; Seedhouse, 1996; Cullen, 1998; Walsh, 2006; Rymes, 2009) that include some features such as interaction patterns, elicitation techniques, feedback strategies, the changes in teacher input, turn-taking and unequal power relationships. Researchers focus on classroom discourse in order to find out what actually happens in the classroom (Carter \& Nunan, 2001). What all of these studies have in common is that analyzing the features classroom discourse is necessary to see how effectively they can facilitate learning (Maftoon \& Rezaie, 2013: p. 109) and develop the students' thinking. Since developing students' higher-order thinking is important, teachers' instruction styles play important role in the initiation of teacher talk in spoken classroom discourse studies. One of the influential factors to encourage interaction in the classroom is the type of questions that teachers ask. Analyzing the nature of teacher questions can provide teachers with valuable insight on how different types of questions affect the learning outcome (Cullen, 1998; Walsh, 2006).

\subsection{Teachers' Questions}

Teacher questions are indispensable components of classroom discourse and they play an important role in facilitating student learning. The types of questions teachers ask during instruction influence the cognitive processes of students (Chin, 2007). Long \& Sato (1983) identified two types of questions that may be asked by teachers in their classrooms; display questions and referential questions. Display questions elicit answers already known by the teacher and are likely to be closed. These questions check only what students know and allow them to give only one acceptable answer; besides they do not encourage longer responses. They demand a single or short response of low-level thinking. Referential questions, on the other hand, are genuinely information-seeking and are likely to be open. These questions serve the purpose of acquiring information. They genuinely seek knowledge and provide students with longer turns. They potentially are a valuable tool in increasing the amount of speech of the students and they demand more thought and generate a longer response and for which the teacher does not know the answer in advance. Long \& Sato (1983) found that in naturalistic discourse, referential questions are more frequent than display questions (Faruji, 2011: p. 1821).

Research on teachers' questions also have revealed that display/closed ended questions are used more than referential/open ended questions in whole-class teaching (Tsui, 1985; Nunan, 1987; Chaudron, 1988; Seedhouse, 1996; Cullen, 1998; Ho, 2005; Walsh, 2006; Yu, 2010). The extensive use of closed ended questions has been criticized by Nunan (1987) and Brock (1986). They argue that closed ended questions do not reflect genuine communication and that they only encourage short, restricted responses while open ended questions can encourage larger and syntactically more complex answers and promote for more interaction and meaningful negotiation (Behnam \& Pouriran, 2009; Maftoon \& Rezaie, 2013).

Open ended questions are not only important tools in engaging children in cognitively challenging conversations and promoting higher-order thinking but they are also found to offer linguistic advantages for children. They help develop children's vocabulary and cognitive skills. In addition to improvements, the use of open ended questions is consistent with knowledge construction, a concept from cognitive psychology where the focus is on the process of working together, and learners construct their own networks of knowledge by connecting new information with their past knowledge and interests (Panitz, 1999). Classrooms are where students learn high-order thinking. In this process, open ended questions play an important role in encouraging students to ex- 
press and elaborate upon their thinking and providing rationales for their thoughts (Lee, Kinzie, \& Whittaker, 2012) and they are also very important in facilitating extended conversation.

An open ended question is defined as a question to which a number of different answers would be acceptable, such as Why is Paris the most memorable place you have ever visited? On the other hand, a closed ended question is the one that expects one possible response as its acceptable answer. It can be answered by "yes" or "no" with factual information, like "Did you have a nice trip?" An important criterion for distinguishing between the two types of questions is, therefore, the number of potentially correct answers (Barnes, 1976; Hargreaves, 1984).

Taken from our data, examples 1) and 2) represent teachers' open ended and closed ended questions and students' answers.

1) Teacher: Senin aklına ne geliyor bahar deyince? (open ended) What comes into your mind when you hear the word spring?

Student 1: Ağaçların çiçek açması geliyor... Flowering trees...

Student 2: Aşk duygusu geliyor.

Love comes into my mind.

2) Teacher: Bahar mevsimini sever misiniz? (closed ended)

Student: Evet. Do you like spring?

Yes.

If we think of dialogue as a vehicle for a process of joint inquiry through which learners construct knowledge, then questions and answers are vital. We do not use questions only to test students' knowledge but also to enable them to reflect, develop and extend their thinking (Grugeon \& Hubbard, 2006: pp. 242-243). In order to teach well, a teacher must be able to question well. Asking good questions smooths the interaction between the teacher and his or her students (Behnam \& Pouriran, 2009: p. 123). Although teachers spend most of their time asking low-level cognitive questions, it is high-level cognitive questions that help students to use higher order thinking or reasoning skills. Ellis (1993) claims that many teachers do rely on low-level cognitive questions in order to maintain the attention of the students and maintain control of the classroom (Behnam \& Pouriran, 2009: p. 123). It has been suggested that one way for teachers to make classes more communicative is by asking fewer closed ended questions and more open ended questions. In a question such as “Tom, what is your idea?" there is no right or wrong answer. This type of question can be expected to lead to more communicative use of language.

Repeated studies have found a much higher rate of closed than open ended questions in teacher discourse. Galton et al. (1999) found that $59.3 \%$ of all teacher questions were closed questions while only $9.9 \%$ questions were open questions; the remaining $30.8 \%$ of questions were concerned with classroom routine (Lefstein \& Snell, 2011: pp. 4-5). The database of Maftoon \& Rezaie (2013) contained 151 questions. Likewise, they found that the teacher asked proportionately more closed ended questions (57\%) than open ended questions (21\%) and the rest of the questions were confirmation checks, rhetorical questions etc. Brock (1986) also found that the teachers who were trained to use open ended questions asked 194 questions and 173 were open ended, however, only 21 were closed ended questions. In contrast, the teachers who were not trained asked 141 questions. Of this 141, only 24 were open and 117 were closed ended questions.

Studies on teacher questioning in Turkey have also revealed a tendency to ask lower level questions (Bay \& Alisinanoğlu, 2012; Bay, 2016). Bay (2016) compared written questions of teacher candidates in Turkey and America. She examined the structure of the questions and according to her findings, the teacher candidates in Turkey asked more than twice as many closed ended questions than the teacher candidates in the US. There are more studies on teacher questioning in Turkey (Baysen, 2006; Büyükalan, 2002, 2007, 2009; Aydemir \& Çiftçi, 2008; Aslan, 2011; Hamiloğlu \& Temiz, 2012; Bay \& Alisinanoğlu, 2012, 2013; Çetinkaya \& Köğce, 2014; Bay, 2011, 2016). However, to our knowledge, there are no studies examining spoken classroom discourse and applying a training intervention designed to teach the value of open ended questions as a way of promoting higher order thinking.

Within the framework outlined so far, this study focuses on the use of open ended questions by teachers in their classrooms. Keeping in mind that one of the aims of this study is to try to create a change in teachers' classroom practices, in particular, in their use of open ended questions; this study tries to achieve an answer to the following question:

What, if any, is the effect of a training program about open ended questions on teachers' questioning beha- 
viors in their classrooms in terms of the following criteria:

1) Teacher experience,

2) Teacher gender,

3) Class level.

\section{Methodology}

\subsection{Participants}

To determine demographic features of the participants, a personal information form was devised, seeking such information as age, experience and gender. The participants were 8 teachers and their students in Turkish classrooms. Teachers participated in the research voluntarily, without any remuneration. They differed in age, teaching experience and gender. Of the 8 participating teachers, 4 were male and 4 were female, and were still serving in the province in which the project was carried out. Table 1 shows the demographic characteristics of these teachers according to age and Table 2 presents characteristics regarding teaching experience.

Concerning age of the participants, their ages ranged from 26 to 56 years old. As illustrated in Table 1, the average age of participants $(n=8)$ was $36.50(S D=9.64)$. Male teachers' $(n=4)$ age was between 31 and $56(M=$ $39.50 ; \mathrm{SD}=11.21)$ and female teachers' $(\mathrm{n}=4)$ age ranged from 26 to $45(\mathrm{M}=33.50$; $\mathrm{SD}=8.18)$.

Years of teaching experience ranged from one year to 30 years. Distribution of the teaching years of the participants was as follows: $50 \%$ were between 1 - 10 years, and the other $50 \%$ were between 10 - 30 years. Teachers $(n=8)$ had an average of 12.75 years of teaching experience $(S D=8.73)$. Male teachers $(n=4)$ had an average of 15.75 years of experience $(\mathrm{SD}=9.91)$ while their female $(n=4)$ counterparts had an average of 9.75 years of experience $(\mathrm{SD}=7.45)$.

\subsection{Research Design}

This study is part of a 2-year project supported by Scientific and Technological Research Council of Turkey (TUBITAK). The experimental research was conducted in secondary schools in different districts of Nevşehir province in central Turkey. The research permission was received from the Ministry of Education, and the schools were randomly selected. The schools generally represented families on the lower level of the socioeconomic status. After the individual school visits of the researchers, 8 teachers from different schools teaching Turkish to $6^{\text {th }}$ and $7^{\text {th }}$ grade classes volunteered to participate in the study.

The research is a single-group based quasi-experimental study which makes use of a pre-test and post-test model. The two treatments included the same content (open ended and closed ended questions) and had the same duration (80 min.) for each class $\left(6^{\text {th }}\right.$ and $7^{\text {th }}$ grade).

Data were collected during the fall and spring semesters of 2012-2013 school year. In terms of content, all

Table 1. Demographic charecteristics of participants $(n=8)$ regarding age.

\begin{tabular}{cccccccc}
\hline & \multicolumn{7}{c}{ Age of Teachers } \\
\hline Subject & Gender & N & Mean & Median & $\begin{array}{c}\text { Standard } \\
\text { Deviation }\end{array}$ & Minimum & Maximum \\
\hline Turkish & M & 4 & 39.500 & 35.500 & 11.210 & 31.000 & 56.000 \\
Turkish & F & 4 & 33.500 & 31.500 & 8.1854 & 26.000 & 45.000 \\
Total & & 8 & 36.500 & 34.000 & 9.636 & 26.000 & 56.000 \\
\hline
\end{tabular}

Table 2. Demographic charecteristics of participants $(n=8)$ regarding experience.

\begin{tabular}{|c|c|c|c|c|c|c|c|}
\hline \multicolumn{8}{|c|}{ Experience of Teachers } \\
\hline Subject & Gender & $\mathrm{N}$ & Mean & Median & $\begin{array}{l}\text { Standard } \\
\text { Deviation }\end{array}$ & Minimum & Maximum \\
\hline Turkish & M & 4 & 15.750 & 13.000 & 9.912 & 7.000 & 30.000 \\
\hline Turkish & $\mathrm{F}$ & 4 & 9.750 & 9.500 & 7.455 & 1.000 & 19.000 \\
\hline Total & & 8 & 12.750 & 12.000 & 8.731 & 1.000 & 30.000 \\
\hline
\end{tabular}


teachers taught the same units specified by the national curriculum. The classes participating in the research used the same Turkish textbook for the appropriate class level. In the single-group design, 8 volunteer teachers were enrolled in a classroom interaction training program in which the focus was on the use of open ended questions. The independent variables of this research consist of the training program, teachers' gender, experience, and class level. The dependent variables in the research are the uses of open ended and closed ended questions.

Before training, in order to prevent any preparation for their lessons, teachers were not given any information on the content of the research. Videotaping took place before and after the training program. Video recording dates were previously scheduled with the teachers and in the pre-training process two 40 -minute lessons of $6^{\text {th }}$ and $7^{\text {th }}$ grade classrooms were video and audio taped during Turkish lessons.

After the first recordings, teachers were given a training covering the use of different question types and dialogicality in the classroom; which refers to polyphony in classrooms where there are dialogues between teachers and students, not only the monologues of the teachers. In the post-training process, again two 40-minute lessons of $6^{\text {th }}$ and $7^{\text {th }}$ grade classrooms were video and audio-recorded and the effects of this training program have been examined with respect to teachers' gender, experience and class level.

\subsection{Recording}

The lessons were recorded using two tripod-mounted digital cameras. Given the inevitability of quiet, unclear, and otherwise difficult-to-transcribe speech in a room with over 20 students, two supplemental digital audio recorders were placed in the opposite corners of each classroom where the video cameras were set up. Due to equipment-related limitations, a few students were outside of the cameras' field of view, but the majority were always visible in each classroom.

One video camera was placed in a front corner and the other camera was placed in a back corner of each classroom. During the lessons, the investigators sat in the back near the camera quietly making field notes, and at the end of each lesson, the equipment was taken down while the teacher and students prepared to leave the classroom. In order to mitigate the teachers' and students' consciousness of the investigators' and equipment's presence during the recording sessions, observation-only visits were made to each classroom prior to recording. Teachers were also told that the goal was to videotape a typical lesson with typical defined as whatever they would have been doing had the class not being recorded. As it worked out, teachers and students seemed to pay virtually no attention to the investigators or the cameras. As a final check, each teacher was asked, after recording, how conscious s/he had been of the investigators' and the cameras' presence and whether s/he had noticed any differences in the students' behaviors. All teachers indicated that there had been no deviations from the norm. Moreover, teachers who try to alter their behavior for the videotaping will likely show some evidence that this is the case. Students, for example, may look puzzled or may not be able to follow routines that are clearly new for them. The researchers have not observed any such unusual behaviors from the students while making field notes. Since no deviations from the norm in class were observed by the teachers and the researchers, students were not asked how conscious they had been of the investigators' and the cameras' presence.

\subsection{Teacher Training Program}

The training program module was developed in order to develop teachers' awareness of cognitive skills and dialogicality. In order to train teachers on question types, PowerPoint ${ }^{\circledR}$ slides and handouts were prepared and handed to the targeted teachers in a series of workshops for a week. In the workshops, teachers received input on open ended questions and how to be more dialogical in their classes through PowerPoint ${ }^{\circledR}$ slides, group discussions, peer-led problem-solving sessions and question-and-answer sessions. Teachers were also provided with tasks and activities during the workshops to enhance implementing authentic open ended questions into instruction. Hence, the training program aimed to change teachers' pedagogical practices and discourse behaviors towards a productive classroom discourse. At the end of the workshops, each teacher adapted an existing lesson plan into a productive classroom discourse by providing open ended questions. After training, all teachers were equipped with questioning strategies and they were expected to put it into practice in their instruction and produce open ended questions during teaching.

\subsection{Transcription and Data Analysis}

The video and audio recordings from the $6^{\text {th }}$ and $7^{\text {th }}$ grade classes of 8 teachers provided the data for the depen- 
dent variables. These recordings have been fully transcribed verbatim into scripts by employing a Conversation Analysis. Each classroom interaction lasted about 160 minutes (80 min. pre-training and 80 min. post-training). Approximately 42.4 hours of 16 Turkish lessons were transcribed into four columns: Non-verbal, Line, Speaker, and Verbal. The Non-verbal column contains all transcribed visible instances of students' raising hands or other non-verbal discourse. The Line column aligns consecutive reference numbers with each utterance. In the Speaker column was recorded the name (e.g. Teacher, name of the student) of the producer of the utterance on the same line in the adjacent Verbal column. Into the Verbal column were transcribed all audible utterances, in standard orthography. In this column, the speech of teachers was coded as utterances. An utterance is defined as a conversational turn that contains one or more syntactic units and it is usually preceded and followed by a pause (Huttenlocher et al., 2010). As a next step, teachers' questions were ascribed to the corresponding question type. Thus, four lessons of each class (two hours of lesson before the training program and two hours after) were analyzed. In addition, data obtained before and after the training program, and analyzed according to question types, were compared.

The present study was a single-group pre-test and post-test design and to assess the difference between two baseline measurements Wilcoxon and Wilcoxon Signed Rank tests were applied on the data. Statistical significance for all measures was deemed at $p<.05$ based on two-independent-sample test. Significant $p$-values $(p<.05)$ are highlighted in grey in Tables displaying pre- and post-test scores.

\section{Results}

In the present study Wilcoxon and Wilcoxon Signed Rank tests were performed on the pre- and post-test scores separately to examine if mean differences were significant in terms of open ended question use, gender, experience, and class level before and after completing the training program.

The results concerning the scores on the use of questions before and after the training program are presented below. These results are followed by a description of the utterances from teachers and students. This will help us to see the effects of the questions on dialogicality in class.

\subsection{Teacher Questions}

In this analysis, the training program and the questions in class as the dependent variable have been taken into account and other variables like gender, experience and class level have been disregarded. Table 3 gives the descriptive statistics of the question types used in class before and after training.

A preliminary inspection of median values showed comparable scores between pre- and post-test. Descriptive comparisons between the median scores of pre- and post-test show an increase in teachers' use of open ended questions after training $(\mathrm{Mdn}=128, p<.05)$.

The teachers' use of open ended questions after the training program influenced the number of utterances students produced.

As shown in Table 4, no significant changes $(p>.05)$ have been observed on the total number of utterances of teachers. However, the analyses revealed positive relationships between the changes from pre- to post-test on the overall utterances of students. There was a significant increase in students' utterances ( $\mathrm{Mdn}=678, p=.009<.05$ ). These results suggest that after the training program, changes in the classroom practices and teachers' use of open ended questions had positive effects on student participation.

Table 3. Descriptive statistics of teacher questions.

\begin{tabular}{ccccc}
\hline & $\begin{array}{c}\text { Pre training test score } \\
\text { Median }\end{array}$ & $\begin{array}{c}\text { Post training test score } \\
\text { Median }\end{array}$ & $\begin{array}{c}p \text { value } \\
\text { (Wilcoxon Test) }\end{array}$ & $\begin{array}{c}\text { TI (Wilcoxon } \\
\text { Signed Rank Test) }\end{array}$ \\
\cline { 2 - 5 } & 8 & 8 & & 46.000 \\
Open ended questions & 80.500 & 128.00 & 0.015 & 24.000 \\
Closed ended questions & 70.500 & 127.500 & 0.188 & -19.000 \\
Affirmative sentences & 1015.000 & 1045.000 & 0.348 & \\
\hline
\end{tabular}




\subsection{Teacher Experience}

Another purpose of this study was to examine whether years of teaching experience had an effect on teachers' pedagogical practices after training. The analysis of classroom interactions based on teacher experience revealed the following results.

The results in Table 5 illustrate that teachers with less than 10 years of experience showed significant scores $(p<.05)$ on the use of open ended questions. No significant differences were found between the pre- to post-test scores of experienced teachers; however an increase in the use open ended questions was observed. Thus, these results revealed that novice teachers increased the number of open ended questions after training. The results suggest that although both groups of teachers showed changes on their classroom practices, less experienced teachers were more willing in putting open ended questions into practice.

\subsection{Teacher Gender}

An analysis was conducted separately for both female and male teachers to examine if female and male teachers' pedagogical practices changed after completing the training program.

Table 6 reveals that female teachers had significant scores $(p<.05)$, on the use of open ended questions. No significant differences were found between the pre- to post-test scores of male teachers' questions; however an increase in the use of open ended questions was observed. In general, these results suggest that female teachers raised more open ended questions after training.

\subsection{Class Level}

Descriptive comparisons in Table 7 between the median scores of pre- and post-test of 6th class and 7th classes show no significant changes.

As seen in Table 7, no significant differences were found between the pre- to post-test scores of open ended question in class 6 and class 7; however an increase in the teachers' use open ended questions was observed in both classes after training. When the average different scores and their sums are considered, the observed differences are positive, meaning that it is in favor of post-test results.

\section{Discussion}

This research was part of a larger study of a 2-year project, extending throughout secondary schools and teacher-

Table 4. Descriptive statistics of teacher and student utterances.

\begin{tabular}{ccccc}
\hline & $\begin{array}{c}\text { Pre training test score } \\
\text { Median }\end{array}$ & $\begin{array}{c}\text { Post training test score } \\
\text { Median }\end{array}$ & $\begin{array}{c}p \text { value } \\
\text { (Wilcoxon Test) }\end{array}$ & $\begin{array}{c}\text { TI (Wilcoxon } \\
\text { Signed Rank Test) }\end{array}$ \\
\hline (n) & 8 & 8 & & -6.000 \\
\hline Teacher utterances & 1195.000 & 1267.000 & 0.782 & 49.000 \\
\hline Student utterances & 481.500 & 678.500 & 0.009 & \\
\hline
\end{tabular}

*Wilcoxon Test; ${ }^{* *}$ Wilcoxon Signed Rank Test.

Table 5. Teacher experience: Pre-test and post-test assessment of teacher utterances.

\begin{tabular}{|c|c|c|c|c|c|c|c|c|}
\hline & \multicolumn{4}{|c|}{ Teacher Experience $<10$} & \multicolumn{4}{|c|}{ Teacher Experience $>10$} \\
\hline & \multicolumn{2}{|c|}{ Median } & \multicolumn{2}{|c|}{ Test } & \multicolumn{2}{|c|}{ Median } & \multicolumn{2}{|c|}{ Test } \\
\hline & Pre-test & Post-test & $p^{*}$ & $\mathrm{Ti}^{* *}$ & Pre-test & Post-test & $p^{*}$ & $\mathrm{TI}^{* *}$ \\
\hline (n) & 4 & 4 & & & 4 & 4 & & \\
\hline Open ended questions & 100.50 & 140.00 & 0.031 & 10.500 & 64.00 & 115.00 & 0.232 & 12.500 \\
\hline Closed ended questions & 78.5 & 69.5 & 0.688 & 2.500 & 142 & 94.5 & 0.164 & 12.500 \\
\hline Affirmative sentences & 1069 & 512.5 & 0.031 & -10.500 & 1275.5 & 969 & 0.322 & 10.500 \\
\hline
\end{tabular}

*Wilcoxon Test; ${ }^{* *}$ Wilcoxon Signed Rank Test. 
Table 6. Gender: Pre-test and post-test assessment of teacher utterances.

\begin{tabular}{|c|c|c|c|c|c|c|c|c|}
\hline & \multicolumn{4}{|c|}{ Female teachers } & \multicolumn{4}{|c|}{ Male teachers } \\
\hline & \multicolumn{2}{|c|}{ Median } & \multicolumn{2}{|c|}{ Test } & \multicolumn{2}{|c|}{ Median } & \multicolumn{2}{|c|}{ Test } \\
\hline & Pre-test & Post-test & $p^{*}$ & $\mathrm{TI}^{* *}$ & Pre-test & Post-test & $p^{*}$ & $\mathrm{TI}^{* *}$ \\
\hline (n) & 4 & 4 & & & 4 & 4 & & \\
\hline Open ended questions & 104 & 139.5 & 0.008 & 18.000 & 64 & 108 & 0.383 & 7.000 \\
\hline Closed ended questions & 95 & 162.5 & 0.250 & 9.000 & 74.5 & 70.5 & 0.578 & 4.000 \\
\hline Affirmative sentences & 1070 & 1069.5 & 0.844 & -2.000 & 980.5 & 790 & 0.313 & -8.000 \\
\hline
\end{tabular}

*Wilcoxon Test; ${ }^{* *}$ Wilcoxon Signed Rank Test.

Table 7. Class level: Pre-test and post-test assessment of teacher utterances.

\begin{tabular}{|c|c|c|c|c|c|c|c|c|}
\hline & \multicolumn{4}{|c|}{ Class 6} & \multicolumn{4}{|c|}{ Class 7} \\
\hline & \multicolumn{2}{|c|}{ Median } & \multicolumn{2}{|c|}{ Test } & \multicolumn{2}{|c|}{ Median } & \multicolumn{2}{|c|}{ Test } \\
\hline & Pre-test & Post-test & $p^{*}$ & $\mathrm{Ti}^{* *}$ & Pre-test & Post-test & $p^{*}$ & $\mathrm{Ti}^{* *}$ \\
\hline (n) & 8 & 8 & & & 8 & 8 & & \\
\hline Open ended questions & 95 & 123 & 0.148 & 11.000 & 78 & 128 & 0.078 & 13.000 \\
\hline Closed ended questions & 102.5 & 142 & 0.313 & 8.000 & 73.5 & 94.5 & 0.813 & 2.000 \\
\hline Affirmative sentences & 1094 & 940 & 0.313 & -8.000 & 964.5 & 1154.5 & 0.843 & -2.000 \\
\hline
\end{tabular}

*Wilcoxon Test; **Wilcoxon Signed Rank Test.

initiated efforts to improve classroom practices and hence student participation. The study was conducted to understand the type of questions raised in classes by teachers who were teaching Turkish. The pre-/post-classroom scores indicated that there was a statistically significant improvement in teachers' use of open ended questions, including an increase in student participation in the classroom. In response to our research question, the analysis of teachers' questioning behaviors at pre- and post-test of the study indicated that teachers asked more open ended questions after the training program. As teachers increased the amount of open ended questions, student utterances also increased. Thus, in the light of these results, it can be concluded that after the training program, teachers' questioning was designed to scaffold students' discursive activity to lead to independent accounts and student participation.

Together with the training program, this study also examined the independent variables of teachers' experience, gender, and class level. Novice teachers were quite willing not only to change their classroom practices, but also to take up entirely new ideas. According to the findings from classroom observation, novice teachers revealed significant changes in their pedagogical practices in terms of their use of open ended questions after training. The results indicated that the most significant difference was found in teachers' experience, that is, less experienced teachers asked more open ended questions than the experienced ones. These results suggest that teachers with less than 10 years of experience had more positive attitudes toward changing classroom practices than did more experienced teachers. Thus, novice teachers might have been more open to changes in teaching practice; however, experienced teachers may have had difficulties changing their classroom practices that have been gained over a long period of time. This experience might have hindered their transfer of new practices into their classrooms. As for gender, female teachers were more open to the possibilities of change and got engaged with the new process. The results revealed that female teachers raised more open ended questions than male teachers.

In terms of class level, both classes revealed positive changes after training; however, no significant differences have been observed between class levels on the use of open ended questions.

Overall, the results of the study indicate that teachers who participated in our project were supported through the training program provided. The professional development model implemented in the current study was intentionally designed to foster the use of open ended questions. Participants tried to use and expand their existing classroom practices and put the new strategies they learned into instruction. Results show the primary objective 
of the project was successfully addressed-providing professional development to improve dialogicality in class.

The results of this study are in accord with previous findings. Nathan, Kim, \& Grant (2009) also compared the classroom discourse before and after teacher participation in professional development activities which aimed to enhance students' classroom participation. They showed that there were changes in classroom discourse structure, in particular, while traditional teacher-led patterns decreased, student-led patterns increased. Turner, Warzon, \& Christensen (2011) investigated patterns of change in teachers' beliefs and practices during a yearlong professional development project. As mentioned earlier, Brock (1986) also found that teachers who had training about the content and the level of questions they ask in their classrooms, asked more open ended questions and that these questions increased the amount of speaking of the students in the classrooms. Galton et al. (1999) also found that most of teacher questions were closed. Maftoon \& Rezaie (2013) found that the teacher asked more closed ended questions than open ended questions. We also observed a similar trend in our study before the training program. However, after the training, we observed a shift from monologic discourse to dialogic discourse; that is, the tide of discourse seemed to change into something more symmetrical than the usual classroom interaction. The type of questions used by a teacher can have a very important role in constructing a facilitative environment, thus, teachers must try to involve the learners in classroom discussions by making them participate in long turns. Our data seem to support the idea that authentic higher-order questions are the ones that elicit more utterances from students, which resulted in more dialogic classrooms.

\section{Conclusion}

The current study specifically focused on the type of questions teachers asked, particularly, open ended questioning. It can be said that by asking significantly more open ended questions, teachers gave their students more opportunities to participate in class. The results of our study suggest that the training program was effective in facilitating positive classroom practices. Moreover, the study provides evidence that student participation increases in lessons where teachers ask more open ended questions and show genuine interest.

This study underscored the complexity of questioning as teaching practice, during the interaction between teacher and student. Since language has the power to shape our consciousness, even a small change in the language of schooling may result in increased student participation, thus students' success. An in-service training program could be designed to raise teachers' awareness in questioning strategies. Through in-service training, we believe that the quality of classroom discourse will improve.

The findings of this study have potential in supporting research insights into practical advice for teachers regarding effective classroom practices, and provide guidelines for teachers to increase their repertoire of questioning skills. Although this study contains rich observational data, it is limited in some respects. First of all, this study was limited in that sample size $(\mathrm{n}=8)$ was small. Another limitation was that this study looked at Turkish lessons only in the $6^{\text {th }}$ and $7^{\text {th }}$ grades. Future multidisciplinary and as well as longitudinal studies are needed to investigate teachers' question types and their effects on students' achievement.

\section{Acknowledgements}

This research is part of a 2-year project (Project number: 112K300) funded by TUBITAK (The Scientific and Technological Research Council of Turkey). We are indebted to TUBITAK for its financial support.

The authors are grateful to the teachers and students who participated in this research, as well as to the principals, parents and district officials who approved it. The authors' sincere thanks go to Tark Aylan for the transcription of the videotapes.

\section{References}

Aslan, C. (2011). Effects of Teaching Applications for Developing Question Asking Skills on Question Forming Skills of Prospective Teachers. Education and Science, 36, 236-249.

Aydemir, Y., \& Çiftçi, Ö. (2008). Edebiyat Öğretmeni Adaylarının Soru Sorma Becerileri Üzerine Bir Araştırma (A Research on Asking Question Ability of Literature Teacher Candidates). Yüzüncü Yıl Üniversitesi Eğitim Fakültesi Dergisi, 5 , 103-115.

Barnes, D. (1976). From Communication to Curriculum. Harmondsworth: Penguin.

Bay, D. N. (2011). Okul Öncesi Öğretmenlerine Verilen Soru Sorma Becerisi Öğretiminin Etkisinin Incelenmesi (The Study 
of the Effect of Teaching Questioning Skill of Preschool Teachers). Unpublished Doctoral Dissertation, Ankara: Gazi University.

Bay, D. N. (2016). The Question Asking Skills of Preschool Teacher Candidates: Turkey and America Example. Journal of Education and Training Studies, 4, 161-169. http://dx.doi.org/10.11114/jets.v4i1.1141

Bay, D. N., \& Alisinanoğlu, F. (2012). The Effect of Teaching Questioning Skills Curriculum Applied to Preschool Education Teachers on Cognitive Taxonomy of Teachers' Questions. Mersin Üniversitesi Eğitim Fakültesi Dergisi, 8, 80-93.

Bay, D. N., \& Alisinanoğlu, F. (2013). The Effect of Teaching Questioning Skills Given to Preschool Teachers on Structure of Teachers' Questions. Journal of Theoretical Educational Science, 6, 1-39.

Baysen, E. (2006). Öğretmenlerin Sınıfta Sordukları Sorular ile Öğrencilerin bu Sorulara Verdikleri Cevapların Düzeyleri (The Levels of Teacher Questions and Student Answers). Kastamonu Eğitim Dergisi, 14, 21-28.

Behnam, B., \& Pouriran, Y. (2009). Classroom Discourse: Analyzing Teacher/Learner Interactions in Iranian EFL Task-Based Classrooms. Porta Linguarum, 12, 117-132.

Brock, C. A. (1986). The Effects of Referential Questions on ESL Classroom Discourse. TESOL Quarterly, 20, 77-59. http://dx.doi.org/10.2307/3586388

Büyükalan, F. S. (2002). Soru-Cevap Yöntemine Ilişkin Öğretimin Öğretmenlerin Soru Sorma Düzeyi ve Tekniklerine Etkisi (The Effect of Question Answer Method Training Given to the Teachers on their Questioning Knowledge and Techniques). Unpublished Doctoral Dissertation, Ankara: Gazi University.

Büyükalan, F. S. (2007). Öğretmenler için Soru Sorma Sanatı (Art of Asking Questions for Teachers). Ankara: Nobel.

Büyükalan, F. S. (2009). Soru Cevap Yöntemi Eğitiminin Öğretmenlerin Soru Sorma Bilgisi ve Soru Sorma Tekniklerine Etkisi (The Effect of Catechetical Method on the Knowledge of Teacher's Interrogation and the Technique of Interrogation). Journal of the Institute of Social Sciences, 3, 167-195.

Carter, R., \& Nunan, D. (2001). Teaching English to Speakers of Other Languages. Cambridge: Cambridge University Press. http://dx.doi.org/10.1017/CBO9780511667206

Çetinkaya, G., \& Köğce, D. (2014). Ortaokul Türkçe Ve Matematik Öğretmenlerinin Öğrencilere Verdikleri Sözel Geribilirimlerin İncelenmesi (An Evaluation of Secondary School Turkish and Mathematics Teachers' Verbal Feedback to Students). Turkish Journal of Social Research, 18, 113-136.

Chaudron, D. (1988). Second Language Classrooms. Cambridge: Cambridge University Press. http://dx.doi.org/10.1017/CBO9781139524469

Chin, C. (2007). Teacher Questioning in Science Classrooms: Approaches that Stimulate Productive Thinking. Journal of Research in Science Teaching, 44, 815-843. http://dx.doi.org/10.1002/tea.20171

Cullen, R. (1998). Teacher Talk and the Classroom Context. ELT Journal, 52/3, 179-187. http://dx.doi.org/10.1093/elt/52.3.179

Ellis, K. (1993). Teacher Questioning Behavior and Student Learning: What Research Says to Teachers. Albuquerque, NM: Paper Presented at the Annual Meeting of the Western States Communication Association.

Ellis, R. (1994). The Study of Second Language Acquisition. Oxford: Oxford University Press.

Faruji, L. F. (2011). Discourse Analysis of Questions in Teacher Talk. Theory and Practice in Language Studies, 1, 18201826. http://dx.doi.org/10.4304/tpls.1.12.1820-1826

Galton, M., Hargreaves, L., Comber, C. Wall, D., \& Pell, A. (1999). Inside the Primary Classroom: 20 Years On. London: Routledge. http://dx.doi.org/10.4324/9780203269329

Grugeon, E., \& Hubbard, L. (2006). Learning through Dialogue. In J. Arthur, T. Grainger, \& D. Wray (Eds.), Learning to Teach in Primary School. Routledge: Falmer.

Hamiloğlu, K., \& Temiz, G. (2012). The Impact of Teacher Questions on Student Learning in EFL. Journal of Educational and Instructional Studies in the World, 2, 1-8.

Hargreaves, D. H. (1984). Teachers’ Questions: Open, Closed and Half-Open. Educational Research, 26, 46-51. http://dx.doi.org/10.1080/0013188840260108

Ho, D. G. E. (2005). Why Do Teachers Ask the Questions They Ask? RELC Journal, 36, 297-310. http://dx.doi.org/10.1177/0033688205060052

Huttenlocher, J., Waterfall, H., Vasilyeva, M., Vevea, J., \& Hedges, L. V. (2010). Sources of Variability in Children’s Language Growth. Cognitive Psychology, 61, 343-365. http://dx.doi.org/10.1016/j.cogpsych.2010.08.002

Lee, Y., Kinzie, M. B., \& Whittaker, J. V. (2012). Impact of Online Support for Teachers’ Open-Ended Questioning in Pre-k Science Activities. Teaching \& Teacher Education, 28, 568-577. http://dx.doi.org/10.1016/j.tate.2012.01.002

Lefstein A., \& Snell, J. (2011). Classroom Discourse: The Promise and Complexity of Dialogic Practice. In S. Ellis, E. McCartney, \& J. Bourne (Eds.), Applied Linguistics and Primary School Teaching (pp. 165-185). Cambridge: Cambridge 
University Press. http://dx.doi.org/10.1017/CBO9780511921605.018

Long, M., \& Sato, C. (1983). Classroom Foreigner Talk Discourse: Forms and Functions of Teachers' Questions. In H. Seliger, \& M. Long (Eds.), Classroom-Oriented Research in Second Language Acquisition (pp. 268-286). Rowley, MA: Newsbury House.

Maftoon, P., \& Rezaie, G. (2013). Investigating Classroom Discourse: A Case Study of an Iranian Communicative EFL Classroom. Iranian Journal of Applied Linguistics (IJAL), 16, 107-128.

Nathan, M. J., Kim, S., \& Grant, T. S. (2009). Instituting Change in Classroom Discourse Structure: Human and Computer Based Motif Analysis. WCER Working Paper No. 2009-1, Madison, WI: University of Wisconsin-Madison, Wisconsin Center for Education Research. http://www.wcer.wisc.edu/publications/workingPapers/papers.php

Nunan, D. (1987). Communicative Language Teaching: Making It Work. ELT Journal, 41, 136-145. http://dx.doi.org/10.1093/elt/41.2.136

Nunan, D. (1989). Understanding Language Classroom. Cambridge: Prentice Hall.

Nunan, D. (1993). Introducing Discourse Analysis. London: Penguin English.

Nystrand, M., Gamoran, A., \& Carbonaro, W. (2001). On the Ecology of Classroom Instruction: The Case of Writing in High School English and Social Studies. In P. Tynjälä, L. Mason, \& K. Londa (Eds.), Writing as a Learning Tool (pp. 57-81). Dordrecht: Kluwer Academic Publishers. http://dx.doi.org/10.1007/978-94-010-0740-5 5

Panitz, T. (1999). Benefits of Cooperative Learning in Relation to Student Motivation. In M. Theall (Ed.), Motivation from within: Approaches for Encouraging Faculty and Students to Excel, New Directions for Teaching and Learning (pp. 59-68). San Francisco, CA: Josey-Bass Publishing.

Roth, M. W. (1996). Teacher Questioning in an Open-Inquiry Learning Environment: Interactions of Context, Content, and Student Responses. Journal of Research in Science Teaching, 33, 710-735.

http://dx.doi.org/10.1002/(SICI)1098-2736(199609)33:7<709::AID-TEA2>3.0.CO;2-R

Rymes, B. (2009). Classroom Discourse Analysis: A Tool for Critical Reflection. Cresskill, NJ: Hampton Press.

Seedhouse, P. (1996). Classroom Interaction: Possibilities and Impossibilities. ELT Journal, 50, 16-24. http://dx.doi.org/10.1093/elt/50.1.16

Tsui, A. B. M. (1985). Analyzing Input and Interaction in Second Language Classrooms. RELC Journal, 16, 8-30. http://dx.doi.org/10.1177/003368828501600102

Turner, J. C., Warzon, K. B., \& Christensen, A. (2011). Motivating Mathematics Learning: Changes in Teachers’ Practices and Beliefs during a Nine-Month Collaboration. American Educational Research Journal, 48, 718-762. http://dx.doi.org/10.3102/0002831210385103

Walsh, S. (2006). Investigating Classroom Discourse. London: Routledge.

$\mathrm{Yu}, \mathrm{W}$. (2010). An Analysis of College English Classroom Questioning. Journal of Language Teaching and Research, 1, 136-144. http://dx.doi.org/10.4304/jltr.1.2.136-144 